\title{
Haemophagocytic syndrome in an adult suffering from pyrexia of unknown origin: an uncommon presentation of tuberculosis: a case report
}

\author{
Wasim Md. Mohosin UI Haque ${ }^{1 *}$, Md. Erfanur Rahman Shuvo ${ }^{1}$, Muhammad Abdur Rahim', Palash Mitra', \\ Tabassum Samad ${ }^{1}$ and Jalaluddin Ashraful Haque ${ }^{2}$
}

\begin{abstract}
Background: Tuberculosis is common, can involve various organs of the body and may have diverse presentations. Haemophagocytic syndrome is one of the rare presentations of tuberculosis carrying a very high mortality. Early detection and institution of anti-tuberculosis medications can be life-saving.

Case presentation: A 23-year-old Bengali man presented with prolonged fever, weight loss, hepatosplenomegaly, pancytopenia and altered liver function. He had high erythrocyte sedimentation rate, positive tuberculin test, granuloma in liver biopsy, and haemophagocytosis was evidenced by histopathological examination of bone marrow. He recovered with anti-tuberculosis therapy.

Conclusion: This case demonstrates that consideration of tuberculosis as an underlying cause of haemophagocytic syndrome could be rewarding and life-saving in this rapidly fatal condition.
\end{abstract}

Keywords: Case report, Haemophagocytic syndrome, Pyrexia of unknown origin, Tuberculosis

\section{Background}

Haemophagocytic syndrome (HPS) or haemophagocytic lymphangiohistiocytosis (HLH) is an uncommon disorder that may present with fever, lymphadenopathy and hepatosplenomegaly. Overactive macrophages phagocytose erythrocytes, leucocytes, platelets and their precursors in bone marrow and reticuloendothelial system. This syndrome can be primary or secondary. Primary HPS is a genetic disorder, occurs in younger age group. Secondary HPS may be triggered by viral infections like Epstein-Barr virus [1], but bacterial infections like tuberculosis (TB) is not uncommon [2-6]. Mortality ranges from 41 to $50 \%$ and in secondary HPS, delay in diagnosis increases mortality $[7,8]$. Therefore, early recognition of

\footnotetext{
*Correspondence: wmmhaque@live.com

${ }^{1}$ Department of Nephrology and Dialysis, Bangladesh Institute of Research and Rehabilitation in Diabetes, Endocrine and Metabolic Disorders (BIRDEM) General Hospital, Dhaka 1000, Bangladesh Full list of author information is available at the end of the article
}

the infective agent and treatment of the cause might be life-saving. We report this case to highlight TB as a cause of HPS in an adult patient and resolution of the disease with anti-TB treatment.

\section{Case presentation}

A 23-year-old Bengali man presented with two-month history of intermittent fever, oral ulcer, anorexia and 9-kg weight loss. He gave history of several episodes of vomiting over five days before hospitalization. He had no other significant history of note, except frequent visit to kalaazar endemic area (Tangail) and sex with commercial sex worker two years back. He denied any history of contact with known TB cases. For his problems he consulted several physicians, underwent various investigations, took several courses of broad spectrum antibiotics and one course of anti-malarial drug without any benefit. His preadmission investigation reports were insignificant except 
raised alanine aminotransferase (ALT) (142 U/L) and ultrasonographic evidence of hepato-splenomegaly.

The patient was very ill [World Health Organization (WHO) performance status-Grade 3] and wasted with a body mass index (BMI) of $16.7 \mathrm{~kg} / \mathrm{m}^{2}$, febrile (temp of $102{ }^{\circ} \mathrm{F}$ ), pulse $112 / \mathrm{min}$, blood pressure $130 / 80 \mathrm{~mm}$ $\mathrm{Hg}$. He had an oral ulcer $(1 \mathrm{~cm} \times 1 \mathrm{~cm})$ on the inner side of left cheek with regular margin and whitish surface without any local lymphadenopathy. He had 7-cm smooth-surfaced, firm, tender hepatomegaly and 3-cm splenomegaly without ascites. Other examination findings including chest, precordium and ocular fundi were normal.

His haemoglobin was $10.3 \mathrm{gm} / \mathrm{dL}$, normochromic-normocytic and erythrocyte sedimentation rate (ESR) was $150 \mathrm{~mm}$ in 1st hour. Hepatic enzymes were raised (ALT $120 \mathrm{U} / \mathrm{L}$, aspartate aminotransferase (AST) $132 \mathrm{U} / \mathrm{L}$, alkaline phosphatase $982 \mathrm{U} / \mathrm{L}$, gamma-glutamyl transferase $(\gamma-G T) 1097 \mathrm{U} / \mathrm{L}$, bilirubin $1.1 \mathrm{mg} / \mathrm{dL})$ as were lactate dehydrogenase (LDH) (1286 U/L) and serum ferritin $(3237 \mathrm{ng} / \mathrm{mL})$. Abdominal ultrasonography revealed hepatosplenomegaly. Immunochromatography (ICT) for kala-azar was negative as were antibody against human immunodeficiency virus [anti-HIV $(1+2)$ ]. Tuberculin test revealed $15 \mathrm{~mm}$ induration at $72 \mathrm{~h}$. Bone marrow examination revealed large histiocytes containing multiple concave nuclei of engulfed myeloid series cells (Fig. 1) suggestive of haemophagocytic syndrome. Biopsy from oral ulcer did not reveal any granuloma or malignancy. Viral serology e.g. IgG for CMV was positive but IgM was negative as was Monospot test. Computed tomography $(\mathrm{CT})$ of abdomen revealed hepatosplenomegaly with multiple isodense lesions in liver and spleen (Fig. 2). Liver biopsy revealed non-caseating granuloma with Langhan's giant cell consistent with tuberculosis (Fig. 3). He had raised triglyceride levels $(2.64 \mathrm{mmol} / \mathrm{L})$.

So, the patient was finally diagnosed as having HPS due to disseminated TB. As the patient was seriously ill and had raised ALT, modified regime of anti-TB chemotherapy (including isoniazide, ethambutol, streptomycin and levofloxacin) along with prednisolone $40 \mathrm{mg} /$ day was started. He became afebrile on 3rd day of starting antiTB drugs but his haematological parameters deteriorated $(\mathrm{Hb} 8.8 \mathrm{gm} / \mathrm{dL}$, total white cell counts $2420 / \mathrm{cmm})$

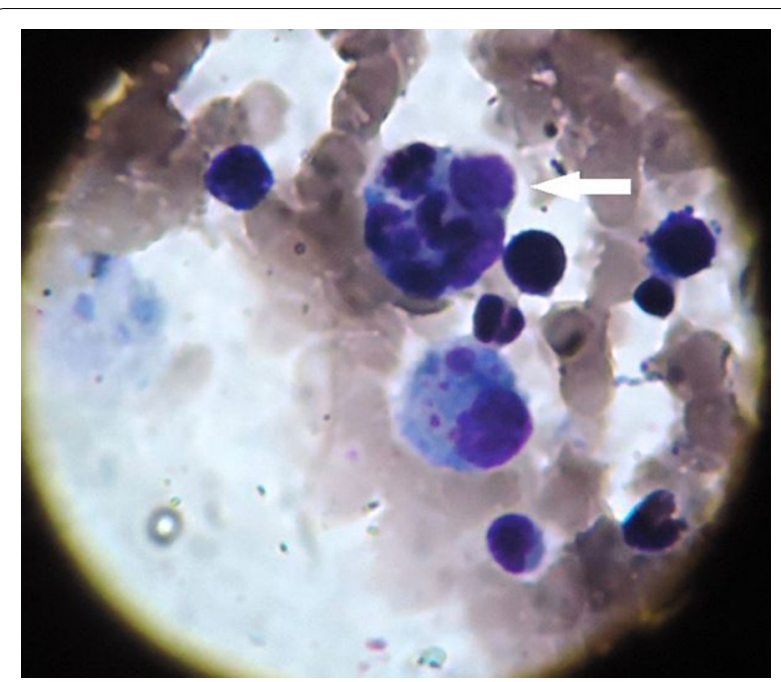

Fig. 1 Bone marrow showing large histiocytes containing multiple concave nuclei of engulfed myeloid series cells (white arrow) suggestive of haemophagocytic syndrome

requiring 2 units of blood transfusion. On 2nd week of anti-TB therapy, his clinical condition, haematological and biochemical parameters improved (Hb $12.1 \mathrm{gm} /$ $\mathrm{dL}$, total white cell counts $5430 / \mathrm{cmm}$, ALT $87 \mathrm{U} / \mathrm{L}$, AST $80 \mathrm{U} / \mathrm{L}$, alkaline phosphatase $540 \mathrm{U} / \mathrm{L}$ ) and we could switch him to standard anti-TB drugs and prednisolone was discontinued. He was discharged on 4th day of standard anti-TB medication. The patient received 6-months anti-TB medications uneventfully and completely cured (Fig. 4).

\section{Discussion}

Primary HPS occurs in young patients and usually associated with genetic disorders $[9,10]$. Secondary HPS affects people of any age. The causes may be variable ranging from infections through autoimmune disorders to malignancy [3]. Overall $3 \%$ of all HPS cases are associated with TB [11] and Tseng et al. [12] found that one-fourth of infection associated HPS among Taiwanese were due to Mycobacterium tuberculosis.

Presenting features of HPS mimics infection, liver disease, haematological malignancies or even encephalitis. A Swedish study reported fever to be the most prominent 


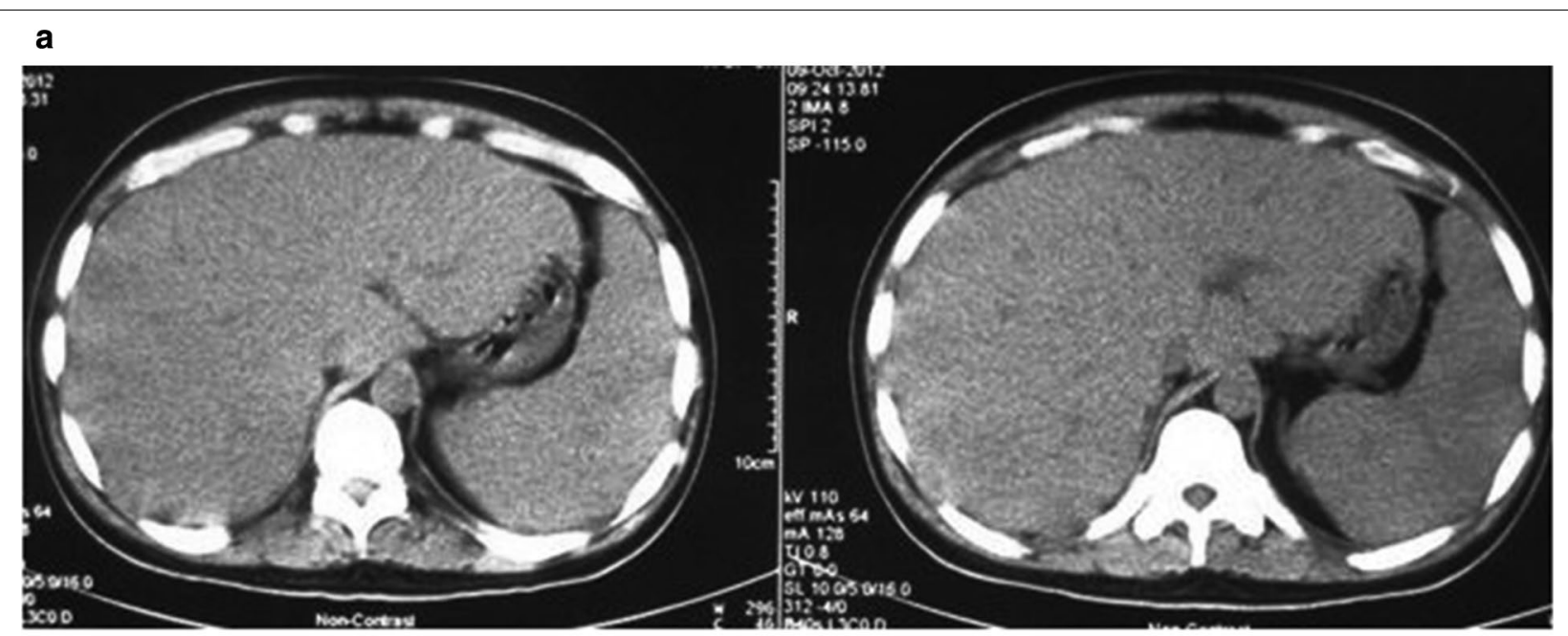

b

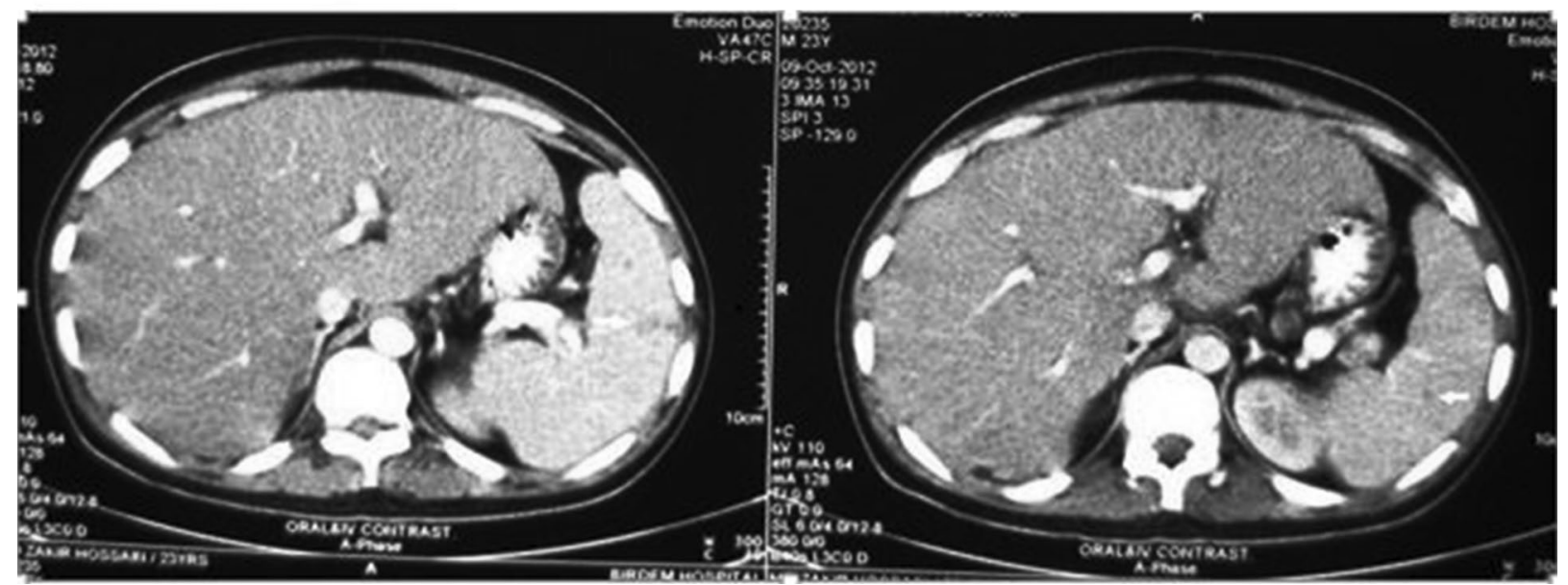

Fig. 2 a, b Computed tomographic (CT) scan of abdomen showing hepatosplenomegaly with multiple isodense lesions in liver and spleen

early feature, followed by hepatomegaly, splenomegaly, neurologic symptoms, rashes and lymphadenopathy in primary HPS [9]. Laboratory parameters include cytopenias, increased ferritin level, morphological evidence of haemophagocytosis, etc. The proposed scheme for diagnosis of HPS recommends presence of at least five out of following nine criteria [13]:

a. fever: peak temperature $>38.5{ }^{\circ} \mathrm{C}$ for 7 or more days

b. splenomegaly: spleen palpated $>3 \mathrm{~cm}$ below the left costal margin c. cytopenia involving two or more cell lines: haemoglobin $<9.0 \mathrm{~g} / \mathrm{dL}$, or platelet $<100,000 / \mu \mathrm{L}$, or absolute neutrophil count $<1000 / \mu \mathrm{L}$

d. hypertryglyceridaemia or hypofibrinogenaemia: fasting triglycerides $>2.0 \mathrm{mmol} / \mathrm{L}$, or more than 3 standard deviations (SD) above the normal value for age, or fibrinogen $<1.5 \mathrm{~g} / \mathrm{L}$, or more than $3 \mathrm{SD}$ below the normal value for age

e. haemophagocytosis: demonstrated in bone marrow, spleen, or lymph node; no evidence for malignancy 

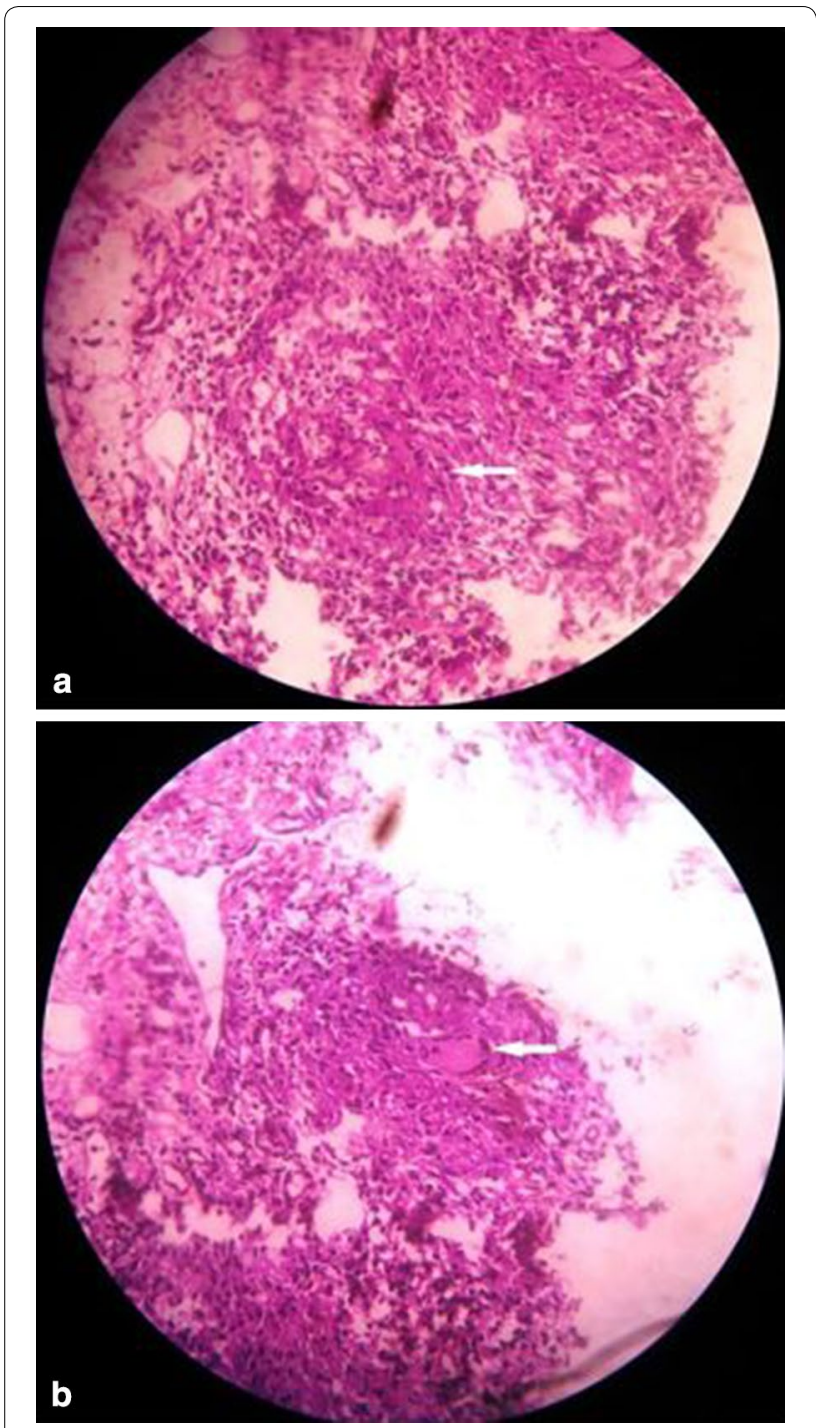

Fig. 3 a, b Liver biopsy showing non-caseating granuloma with Langhan's giant cell (white arrow) consistent with tuberculosis

\section{f. hepatitis}

g. low or absent natural killer cell activity

h. serum ferritin level $>500 \mu \mathrm{g} / \mathrm{L}$ (although $>3000 \mu \mathrm{g} / \mathrm{L}$ is a more realistic cut off to exclude infections and

i. soluble CD25 (sIL-2 receptor) $>2400 \mathrm{U} / \mathrm{mL}$ (note age-related norms).

Our patient had seven out of these nine criteria. Our center does not have the capacity to test for natural killer cell activity and soluble CD25.

Haemophagocytosis can be demonstrated among biopsy samples from bone marrow, liver or spleen, and bone marrow is an excellent sample for exhibiting haemophagicytosis associated with TB [2-4, 13]. As TB-associated HPS is rare, patients have been treated by different approaches. Brastianos et al. [8] in a review of 36 such cases found that anti-TB therapy alone showed better survival than combination of anti-TB drugs and various immunomodulatory therapies. In such cases, delay in diagnosis was found to be the most important factor for poor outcome [8]. Our patient responded well to anti-TB treatment, prednisolone was administered only in initial periods.

It should be mentioned that being a high TB-burden country, in our clinical practice we encounter many cases of disseminated TB even in immunocomtetent individuals. Delay in establishing an aetiological diagnosis or haematogenous spread may be contributory in this particular case for such an advanced presentation.

\section{Conclusion}

Although associated with multiple conditions, TB should always be considered as cause of HPS in countries like Bangladesh where TB is endemic. An early diagnosis and treatment with appropriate anti-TB drugs is life-saving.

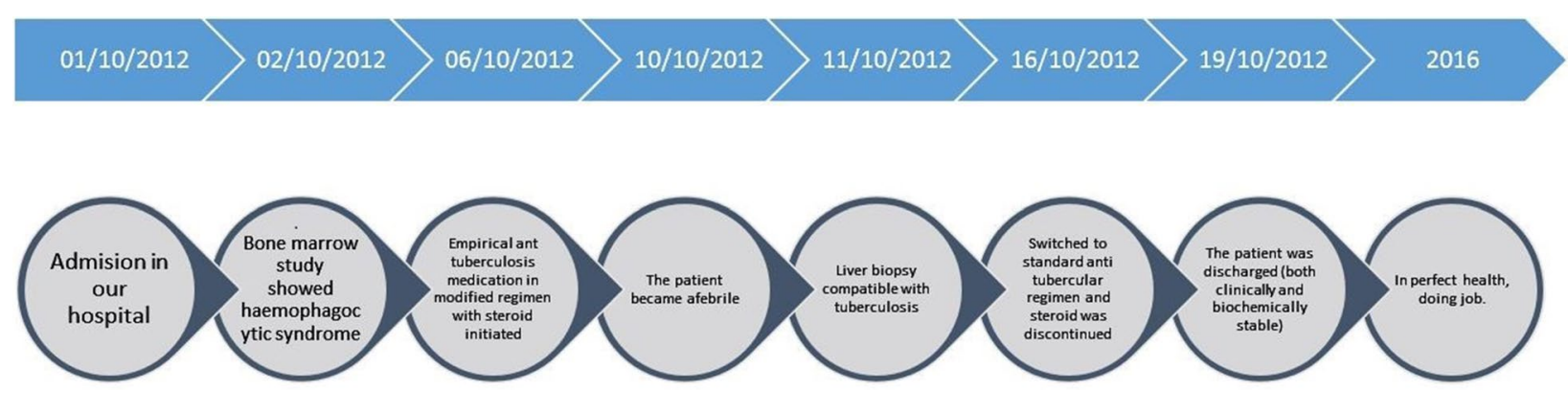

Fig. 4 Timeline 


\section{Abbreviations}

HPS: haemophagocytic syndrome; HLH: haemophagocytic lymphangiohistiocytosis; TB: tuberculosis; ALT: alanine aminotransferase; WHO: World Health Organization; BMI: body mass index; AST: aspartate aminotransferase; $\gamma$-GT: gamma-glutamyl transferase; LDH: lactate dehydrogenase; ECG: electrocardiography; ECHO: echocardiography; ICT: immunochromatography; HBsAg: hepatitis B virus surface antigen; HCV: hepatitis C virus; VDRL: veneral disease research laboratory; TPHA: treponema pellidum haemaglutinine assay; HIV: human immunodeficiency virus; ANA: antinuclear antibody; RF: rheumatoid factor; CMV: cytomegalovirus; CT: computed tomographic; SD: standard deviation.

\section{Authors' contributions}

WMMH has managed the patient, done literature review, manuscript preparation and final approval of the draft. MERS has participated in management of the patient, data collection, literature search and drafting the manuscript. MAR has done literature search, editing the draft and final approval of the draft. PM has done literature review and drafting the case report. TS has done literature search, had critical intellectual contribution to the draft and final approval of the manuscript. JAH was the key microbiologist, had taken part in decision making in treating the patient and editing the draft. All authors read and approved the final manuscript.

\section{Author details}

${ }^{1}$ Department of Nephrology and Dialysis, Bangladesh Institute of Research and Rehabilitation in Diabetes, Endocrine and Metabolic Disorders (BIRDEM) General Hospital, Dhaka 1000, Bangladesh. ${ }^{2}$ Ibrahim Medical College, Shahbag, Dhaka 1000, Bangladesh.

\section{Acknowledgements}

The authors express their acknowledgement to Dr. Mohsin Kabir, Junior Consultant, Department of Gastro-Intestinal, Hepatobiliary and Pancreatic Diseases, BIRDEM General Hospital for his co-operation in doing liver biopsy, Professor Dr. Md. Sirajul Islam, Professor of Haematology, BIRDEM General Hospital, for his co-operation in doing and reporting bone marrow biopsy and Dr. Md. Delwar Hossain, Associate Professor, Department of Internal Medicine and Pulmonology, BIRDEM General Hospital and Professor Khwaja Nazim Uddin, Professor of Medicine of BIRDEM General Hospital for their co-operation in managing this patient.

\section{Competing interests}

The authors declare that they have no competing interests.

\section{Consent to publish}

Written informed consent was obtained from the patient for publication of this Case Report and any accompanying images. A copy of the written consent is available for review by the Editor-in-Chief of this journal.
Received: 2 August 2016 Accepted: 16 February 2017

Published online: 27 February 2017

\section{References}

1. Janka GE. Haemophagocytic syndromes. Blood Rev. 2007;21(5):245-53.

2. Naha K, Dasari S, Vivek G, Prabhu M. Disseminated tuberculosis presenting with secondary haemophagocytic lymphangiohistiocytosis and Poncet's disease in an immunocompetent individual. BMJ Case Rep. 2013. doi:10.1136/bcr-2012-008265.

3. Cherif E, Feki NB, Hassine LB, Khalfallah N. Haemophagocytic syndrome with disseminated intravascular coagulation associated with tuberculosis BMJ Case Rep. 2013. doi:10.1136/bcr-2013-008743.

4. Li J, Yu S, Wang M, Chen HB, Wang W. A case of hemophagocytic lymphohistiocytosis syndrome caused by severe tuberculosis and literature review. Zhonghua Jie He He Hu Xi Za Zhi. 2012;35(10):766-9.

5. Aggarwal P, Kumar G, Dev N, Kumari P. Haemophagocyticlymphangiohistiocytosis: a cause of rare but fatal outcome in tuberculosis. BMJ Case Rep. 2012. doi:10.1136/bcr-2012-006982.

6. Manoj EM, Srigrisha R, Raghunathan MK. Hepatic tuberculosis presenting with extreme hyperferritinaemia masquerading as adult-onset Still's disease: a case report. J Med Case Rep. 2012;6:195.

7. Kaito K, Kobayashi M, Katayama T, Otsubo H, Ogasawara Y, Sekita T, et al. Prognostic factors of haemophagocytic syndrome in adults: analysis of 34 cases. Eur J Haematol. 1997;59(4):247-53.

8. Brastianos PK, Swanson JW, Torbenson M, Sperati J, Karakousis PC. Tuberculosis associated haemophagocytic syndrome. Lancet Infect Dis. 2006;6(7):447-54.

9. Henter Jl, Elinder G, Soder O, Ost A. Incidence in Sweden and clinical features of familial haemophagocytic lymphangiohistiocytosis. Acta Paediatr Scand. 1991;80(4):428-35.

10. Ishii E, Ohga S, Imashuku S, Kimura N, Ueda I, Morimoto A, et al. Review of haemophagocytic lymphangiohistiocytosis $(\mathrm{HLH})$ in children with focus on Japanese experiences. Crit Rev Oncol Haematol. 2005;53(3):209-23.

11. Creput C, Galicier L, Buyse S, Azoulay E. Understanding organ dysfunction in haemophagocytic lymphangiohistiocytosis. Intensive Care Med. 2008;34:1177-87.

12. Tseng YT, Sheng WH, Lin BH, Lin CW, Wang JT, Chen YC, et al. Causes, clinical symptoms and outcomes of infectious diseases associated with haemophagocytic lymphangiohistiocytosis in Taiwanese adults. J Microbiol Immunol Infect. 2011;44(3):191-7.

13. Henter JI, Elinder G, Ost A. Diagnostic guidelines for hemophagocytic lymphohistiocytosis: The FHL Study Group of the Histiocyte Society. Semin Oncol. 1991;18(1):29-33.

\section{Submit your next manuscript to BioMed Central and we will help you at every step:}

- We accept pre-submission inquiries

- Our selector tool helps you to find the most relevant journal

- We provide round the clock customer support

- Convenient online submission

- Thorough peer review

- Inclusion in PubMed and all major indexing services

- Maximum visibility for your research

Submit your manuscript at www.biomedcentral.com/submit 